\title{
SEASONAL CHANGES OF LEAF NITROGEN CONTENT IN TREES OF AMAZONIAN FLOODPLAINS
}

\author{
Pia PAROLIN', Nicole ARMBRÜSTER ${ }^{2}$, Wolfgang J. JUNK ${ }^{1}$
}

Abstract - In Amazonian floodplains the trees are exposed to extreme flooding of up to 230 days a year. Waterlogging of the roots and stems affects growth and metabolic activity of the trees. An increased leaf fall in the aquatic period and annual increment rings in the wood indicate periodical growth reductions. The present study aims at documenting seasonal changes of metabolism and vitality of adult trees in the annual cycle as expressed by changes of leaf nitrogen content. Leaves of six tree species common in floodplains in Central Amazonia and typical representants of different growth strategies were collected every month between May 1994 and June 1995 in the vicinity of Manaus, Brazil. Mean leaf nitrogen content varied between 1.3\% and $3.2 \%$ in the non-flooded trees. Three species showed significantly lower $\mathrm{N}$ content in the flooded period ( $\mathrm{p}=0.05,0.001,0.001)$, the difference ranging $20-25 \%$ lower than in the nonflooded period. Two species showed no significant difference while Nectandra amazonum showed $32 \%$ more $\mathrm{N}$ in the flooded season $(\mathrm{p}=0.001)$. Leaf nitrogen content was generally high when new leaves were flushed (in the flooded period) and decreased continuously thereafter in all species. Three species showed an additional peak of nitrogen during the first month of the terrestrial phase, in leaves which had flushed earlier, indicating that flooding may disturb nitrogen uptake.

Key-words: leaf nitrogen, growth strategy, waterlogging, várzea, floodplain, Amazonia.

\section{Mudanças Sazonais do Conteúdo de Nitrogênio nas Folhas de Árvores das Áreas Inundáveis da Amazônia.}

Resumo - Em áreas inundáveis da Amazônia as árvores estão expostas a extremos de inundação de até 230 dias por ano. A submersão das raizes e do tronco afeta o crescimento e as atividades metabólicas das árvores. $\mathrm{O}$ aumento da queda de folhas na fase aquática e o incremento anual nos anéis do lenho, indicam reduções de crescimento periódicas. O presente estudo visa documentar em um ciclo anual mudanças sazonais no metabolismo e vitalidade de árvores adultas, expressas pelas mudanças no conteúdo de nitrogênio das folhas. Seis espécies de árvores comuns em áreas inundáveis da Amazônia Central e típicos representantes de diferentes estratégias de crescimento, tiveram suas folhas coletadas a cada mês entre maio de 1994 e junho de 1995 , nas cercanias da cidade de Manaus, Brasil. A média do conteúdo de nitrogênio variou entre 1,3\% e 3,2\% em árvores não inundadas. Tres espécies tiveram concentrações de $\mathrm{N}$ significativamente menores no periodo de inundação $(\mathrm{p}=0,05,0,01,0,01)$, sendo 20 a $25 \%$ menores que as concentrações no periodo não inundado. Duas espécies não tiveram diferenças significativas, enquanto Nectandra amazonum teve $32 \%$ mais $\mathrm{N}$ quando inundada $(\mathrm{p}=0.001)$. O conteúdo de nitrogênio foliar foi geralmente alto quando brotaram folhas novas (no período inundado) seguido por um decréscimo contínuo, embora três espécies atingiram seu pico de conteúdo de $\mathrm{N}$ no primeiro mes da fase terrestre, em folhas que haviam brotadas antes, indicando que a inundação possivelmente inibe a assimilação de nitrogênio.

Palavras-chave: nitrogênio, folhas, estratégias de crescimento, inundação, várzea, áreas inundáveis, Amazônia.

\section{Introduction}

In Amazonian floodplains the trees are exposed to extreme flooding which can last up to 230 days a year (Junk, 1989). Waterlogging of the roots and the stems affects growth and metabolic activity of the trees because

'Max-Planck-Institute for Limnology, Tropical Ecology, P.O. Box 165, 24302 Plön, Germany ${ }^{2}$ Universität Oldenburg, Pflanzenökologie, Carl-von-Ossietzky Str. 9-11, 26111 Oldenburg, Germany 
root growth is impeded and the absorption of water and nutrients is inhibited (Gill, 1970; Kozlowski, 1984; Blom \& Voesnek, 1996). Only adapted species can tolerate these conditions, e.g. by reducing the metabolic activity as in the temperate species Alnus rubra, Fraxinus latifolia, Nyssa aquatica, Taxodium distichum or Quercus lyrata (Ewing, 1996; Pezeshki, 1987; Pezeshki et al., 1996). Some species, for example the tropical trees Hymenaea courbaril and Chorisia speciosa, can maintain or even increase growth and photosynthetic activity despite flooding (Joly \& Crawford, 1982).

About 100 tree species per hectare - to a large extent habitat-endemic - grow in Amazonian floodplains (Worbes 1997). Independent of their growth strategies, whether pioneers or non-pioneers (sensu Swaine \& Whitmore, 1988), evergreen or deciduous species, they must have physiological, anatomical and morphological adaptations to be able to withstand the prolonged flooding. In fact, in selected species the formation of adventitious roots, lenticels, stem hypertrophy, and pressure ventilation were documented (Schlüter \& Furch, 1992; Schlüter et al., 1993, Parolin, 2000; 2001; Waldhoff et al., 1998; Graffmann 2000). Yet, up to date, very little is known about tree ecophysiology in this ecosystem, and about its changes in the course of the year. Many tree species form annual increment rings indicating periodical growth reductions (Worbes, 1986; 1989). This might be linked to leaf phenology: leaf fall is in- creased in the aquatic period (Ferreira, 1991; Worbes, 1992; Wittmann \& Parolin, 1999), perhaps because of the necessity to reduce the transpirational surface of the trees. Respiration, photosynthetic assimilation, leaf chlorophyll content and water potential are lower in flooded trees than in non-flooded ones (Scholander \& Perez, 1968; Furch, 1984; Schlüter, 1989; Schlüter \& Furch, 1992; Schlüter et al., 1993; Parolin, 1997).

The knowledge which exists to date about the metabolic activity of trees in Amazonian floodplains indicates a periodicity which is closely linked to the flooding periodicity. Yet, a continuous documentation of growth activity of adult trees along the year is missing or available only in non-published theses (Parolin, 1997; Maia, 1997; Armbrüster, 1999). The present study aims at documenting seasonal changes of metabolism and vitality of adult trees in an annual cycle. The assimilating organs which are indicators of the vitality of a tree (Medina, 1984; Walters \& Reich, 1989) have changes of their nitrogen content which might be used as an indicator for stress reactions in the course of the year. Leaf nitrogen content depends on leaf age (Field, 1983; Field \& Mooney, 1983; Reich et al,, 1991, 1994): senescent leaves have lower nitrogen concentrations than young leaves. On the other hand, environmental factors, including the availability - or excess of water, may regulate the efficiency of nitrogen use for growth (Raison \& Myers, 1992). Leaf nitrogen content is therefore used here as a parameter for 
the documentation of seasonal changes of tree vitality in the floodplains.

\section{Material and Methods}

Study trees - Six tree species were chosen, all common to várzea floodplains in Central Amazonia and typical representants of different growth strategies and flood tolerance (Prance, 1979; Worbes et al., 1992): Cecropia latiloba (Cecropiaceae, "Embaúba", evergreen pioneer), Senna reticulata (Caesalpiniaceae, "Matapasto", evergreen pioneer), Nectandra amazonum (Lauraceae, "Louro", evergreen non-pioneer), Crateva benthamii (Capparidaceae, "Catoré", deciduous non-pioneer), Tabebuia barbata (Bignoniaceae, "Capitari", deciduous nonpioneer) and Vitex cymosa (Verbenaceae, "Tarumã", deciduous non-pioneer).

Only adult, healthy trees were chosen which were situated between 21 and 27 meters above sea-level (m asl) and were subjected to a period of inundation of eight (Cecropia latiloba and Vitex cymosa), five (Crateva benthamii and Tabebuia barbata) and four (Senna reticulata and Nectandra amazonum) months.

Study site - The marked trees were situated at the Costa do Catalão (Barranco and Fazenda Lira) in the vicinity of Manaus, Brazil, near the confluence of the Amazon (Solimões) River with the Negro River (approximately $3^{\circ} \mathrm{S}, 60^{\circ} \mathrm{W}$ ).

Climate and hydrology - Rainfall shows a marked dry season between June and September, and a rainy season from December to May (Fig. 1). Mean annual rainfall ranges from
1700 to $2300 \mathrm{~mm}$, and mean monthly temperature lies between $26.3^{\circ} \mathrm{C}$ and $27.2^{\circ} \mathrm{C}$. River level is markedly seasonal. The rising phase is between late December and early July, while the draining period lasts from the end of July to the end of November (Fig. 2). During the high water period, most deciduous trees lose their leaves.

\section{Measurements of leaf nitrogen} content - The study was performed between May 1994 and June 1995. Non-flooded sun-exposed leaves of each of five marked individuals per species were collected at monthly intervals in the field. Only fully expanded leaves were chosen, except for the months where only senescent or young leaves were present on the trees, as was the case in the three deciduous species. The leaves were chosen from the lower canopy, i.e. from similar positions on the tree (Hikosaka et al. 1994). The collected leaves of the five trees per species were mixed in paper bags, transported on ice and in the dark to the Amazon Research Institute in Manaus (INPA) and oven dried in paper bags for 36 hours at $60^{\circ} \mathrm{C}$.

Leaf nitrogen content was determined with the method of Kjeldahl using the "Vapodest 5" (Gerhardt, Kjeldaltherm Jürgens): $0.2 \mathrm{~g}$ of finely ground leaves were used, with $5 \mathrm{ml}$ $\mathrm{H}_{2} \mathrm{SO}_{4}(98 \%)$ and 1 Kjeltabs ST $(0.3 \mathrm{~g}$ $\mathrm{K}_{2} \mathrm{SO}_{4}, 0.0035 \mathrm{~g}$ Selenium) as catalyst.

\section{Results}

Leaf nitrogen content of the six species varied between $1.3 \%$ and 


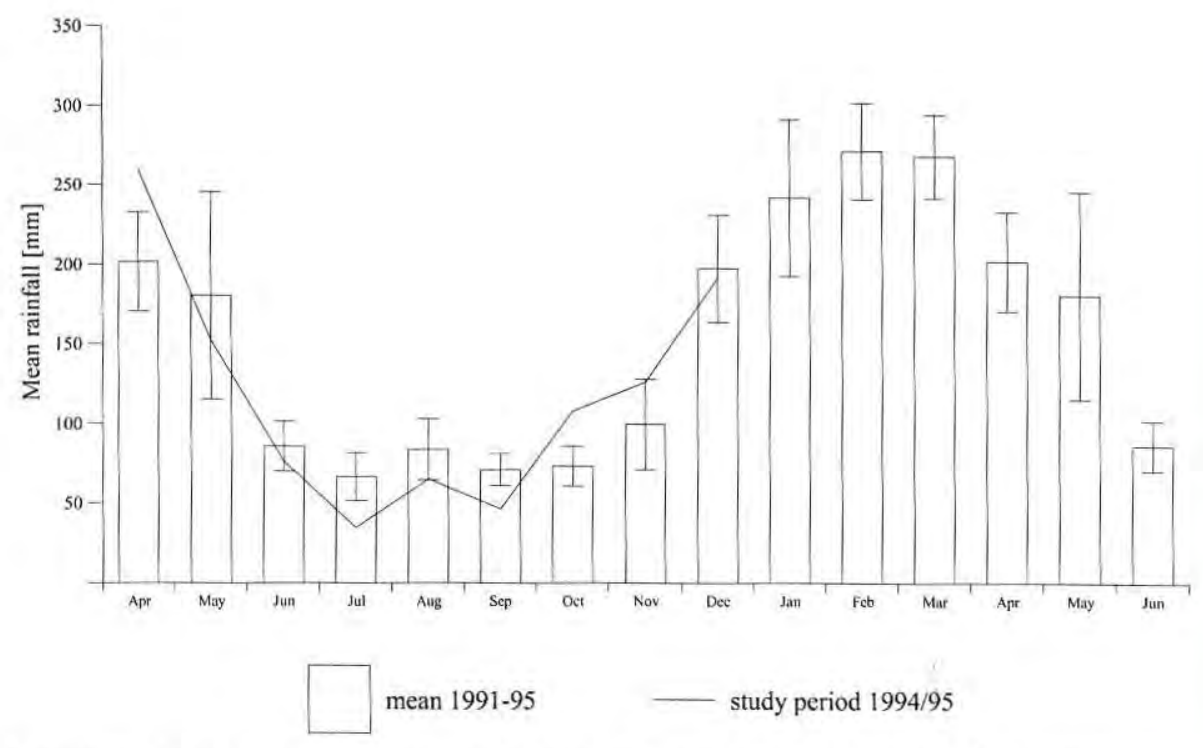

Figure 1. Monthly rainfall measured near the study sites on the Ilha de Marchantaria: mean rainfall in the years 1991 to 1995 (bars) with standard deviation, and in the study period 1994/ 5 (line) .

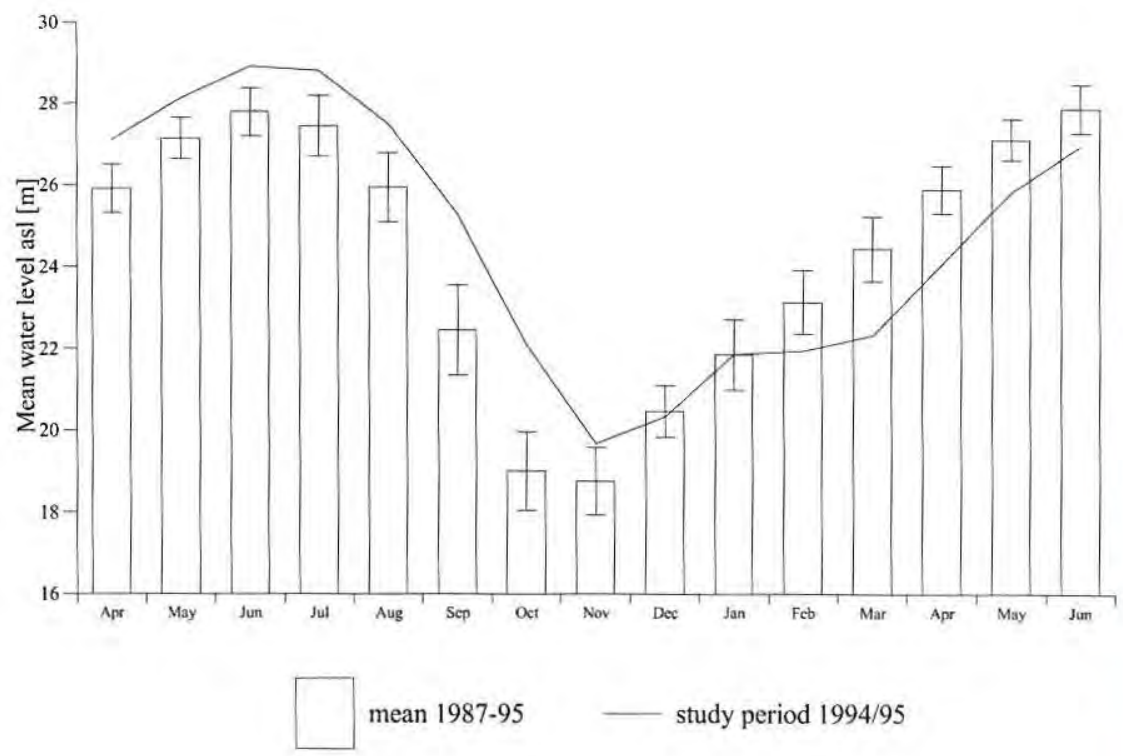

Figure 2. Monthly water level above sea level of the Rio Negro measured at the port of Manaus: mean water level in the years 1987 to 1995 (bars) with standard deviation, and in the study period 1994/5 (line). 
$3.2 \%$ in the terrestrial phase (Tab. 1$)$. In Nectandra amazonum, the lowest nitrogen contents were measured, the highest were found in Senna reticulata. The two pioneers Cecropia latiloba and Senna reticulata, and Crateva benthamii had similar values, which could reach a maximum of $3.4 \%$. In Nectandra amazonum, Tabebuia barbata and Vitex cymosa the nitrogen contents did not exceed $2.6 \%$.

Three species showed significantly lower leaf nitrogen content in the waterlogged phase, the difference ranging 20-25\% lower than the terrestrial phase (Tab. 1). Two species showed no significant difference between the two seasons while Nectandra amazonum showed a $32 \%$ increase in mean leaf $\mathrm{N}$ content in the flooded season compared to the nonflooded period.

In the annual cycle, leaf nitrogen content was generally high in the months when new leaves were flushed and were fully expanded, and maximum values could be measured in the ter- restrial as well as in the aquatic period (Fig. 3). Leaf nitrogen content decreased continuously after leaf expansion in all species, but three species, Cecropia latiloba, Tabebuia barbata and Vitex cymosa, flushed in the inundated period and reached a peak in October, the first month of the nonflooded period.

\section{Discussion}

\section{Changes of nitrogen content} in the annual cycle - Leaf nitrogen content of the six analysed species showed characteristic changes in the annual cycle. The general decrease of nitrogen content after the expansion of new leaves (Fig. 3) indicates that it was linked to leaf development. Nitrogen content is highest in newly developed young leaves and decreases with leaf age (Field, 1983; Field \& Mooney, 1983; Reich et al., 1994). In the study trees, all species had elevated nitrogen concentrations when new leaves were flushed, which occured in the flooded period (Worbes, 1997). Three species

Table 1. Mean leaf nitrogen content of the six study species in the non-flooded and waterlogged months: minimum and maximum measured nitrogen contents, average of the measurements in the terrestrial phase, average of the measurements in the aquatic phase with standard deviations, difference between terrestrial $(=100 \%)$ and aquatic phase, F-ratio ANOVA and statistical probability $\mathrm{P}(* \mathrm{p}=0.05 ; * * \mathrm{p}=0.01 ; * * * \mathrm{p}=0.001 ; \mathrm{n} . \mathrm{s}$. not significant).

\begin{tabular}{|c|c|c|c|c|c|c|}
\hline Species & $\begin{array}{c}\min -\max \\
{[\%]}\end{array}$ & $\begin{array}{c}\text { Terrestrial phase } \\
{[\%]}\end{array}$ & $\begin{array}{c}\text { Aquatic phase } \\
{[\%]}\end{array}$ & $\begin{array}{c}\text { Difference } \\
{[\%]}\end{array}$ & F-ratio & $P$ \\
\hline C. latiloba & $2.1 \cdot 3.6$ & $2.55 \pm 0.4$ & $2.48 \pm 0.4$ & -2.5 & 0.27 & n.s. \\
\hline S. reticulata & $2.0-3.7$ & $3.17 \pm 0.5$ & $2.5 \pm 0.2$ & -21.1 & 23.83 & $* * *$ \\
\hline N. amazonum & $1.0 \cdot 2.2$ & $1.31 \pm 0.2$ & $1.72 \pm 0.4$ & 31.6 & 14.43 & $\cdots$ \\
\hline C. benthamii & $1.4 \cdot 3.4$ & $2.56 \pm 0.5$ & $2.35 \pm 0.6$ & -8.1 & 1.18 & n.s. \\
\hline T. barbata & $0.9 \cdot 2.4$ & $1.86 \pm 0.2$ & $1.49 \pm 0.5$ & -19.7 & 5.99 & $\cdot$ \\
\hline V. cymosa & $0.8 \cdot 2.6$ & $1.86 \pm 0.4$ & $1.4 \pm 0.3$ & -24.6 & 17.36 & $\ldots *$ \\
\hline
\end{tabular}



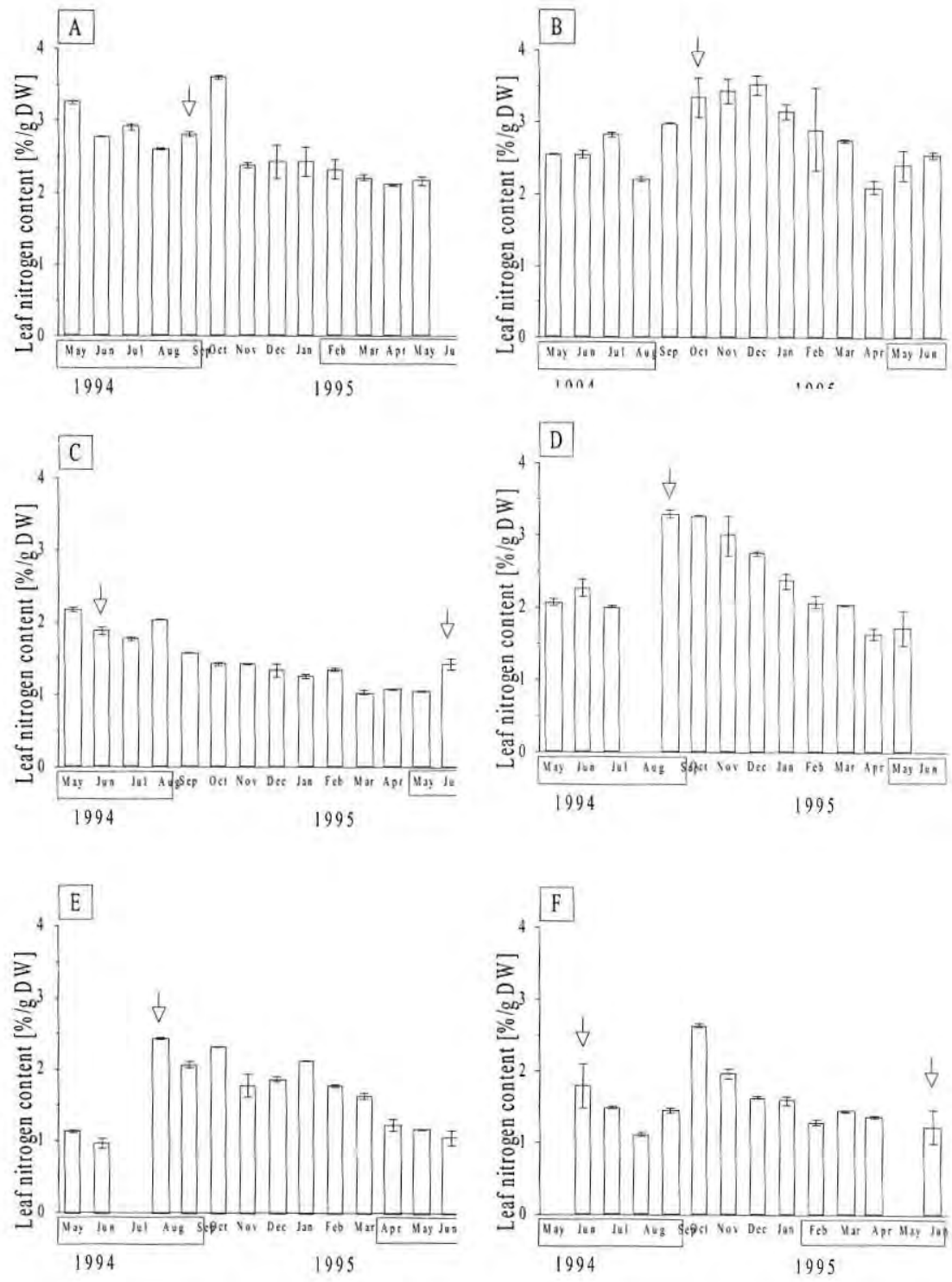

Figure 3. Leaf nitrogen content in the annual cycle in the six chosen species (A Cecropia latiloba, B Senna reticulata, C Nectandra amazonum, D Crateva benthamii, E Tabebuia barbata, F Vitex cymosa). Monthly nitrogen content as percent of leaf dry weight, with standard deviation, between May 1994 and June 1995. Sample size per species and month $(n)=3$ measurements of combined samples from 5 trees. Months in box $=$ aquatic phase. Arrow $=$ flush of new leaves. 
had significantly different nitrogen contents in the flooded phase (Tab. 1) which might be directly linked to waterlogging. Flooding may disturb the capacity of the roots for nitrogen uptake. Only few species, e.g. Oryza spp., are known to be able to take up nutrients from waterlogged soils (Hook, 1984). This was never analysed in soils which are flooded by several meters of water like in Amazonian floodplains. With flood end, some species showed increased nitrogen content even without flushing new leaves (Fig. 3: A, E, F). These peaks measured in October may be related to the fact that most plants respond to increased nitrogen availability with significant increases in leaf nitrogen content (Osman \& Milthorpe, 1971; Gulmon \& Chu, 1981). With the end of submergence, the roots recover their normal functioning (Meyer, 1991) and the increased nitrogen uptake is reflected by higher leaf nitrogen values.

The high nitrogen content of the new leaves flushed at high water levels might not result from an increased uptake of nitrogen, but from the internal cycling of stored reserves (Millard \& Proe, 1991; Sanchez et al., 1991). A key process in such internal cycling is the withdrawal of nitrogen from leaves during senescence for storage in shoots and roots (May \& Killingbeck, 1992). $40-70 \%$ of leaf nitrogen content were resorbed in floodplain trees of the temperate regions (Tremolieres et al., 1999), and the resorption from senescent leaves of Vaccinium was higher in deciduous than in evergreen species (Gerdol et al., 2000).

Role of growth strategies -
The pioneer species had the highest nitrogen concentrations with about $3 \%$. Similar values were found in Cecropia ficifolia in the Terra Firme (Ellsworth \& Reich, 1996). Fast-growing species typically have a higher total organic nitrogen concentration per unit plant weight, allocate more nitrogen to the leaves, and have a higher photosynthetic nitrogen use efficiency (Poorter \& Remkes, 1990). The three deciduous species had higher leaf nitrogen contents than the evergreen Nectandra amazonum, which reflects a pattern found also in savanna trees, where deciduous trees have higher nitrogen contents than evergreen species (Medina, 1984).

There was a significant difference between leaf nitrogen content of flooded and non-flooded stages for four species, and no significant pattern for two species, but the changes in the annual course did not appear to be related to pioneer or non-pioneer growth habit, or to evergreenness and deciduousness.

\section{Conclusions}

The data of the present study shows that seasonal changes of flooding are reflected by changes of leaf nitrogen content in the study period. Several types of changes occurred which are summarized in Table 2. How nitrogen content and flooding are linked and which physiological processes are responsible for the interactions is not yet understood. Further investigations with regard to biochemical, anatomical and morphological adaptations in the rooting zone are needed here. 
Table 2. Overview over the types of changes in leaf nitrogen content in six study species.

C. latiloba S. reticulata N. amazonum C. benthamii $T$. barbata V.cymosa

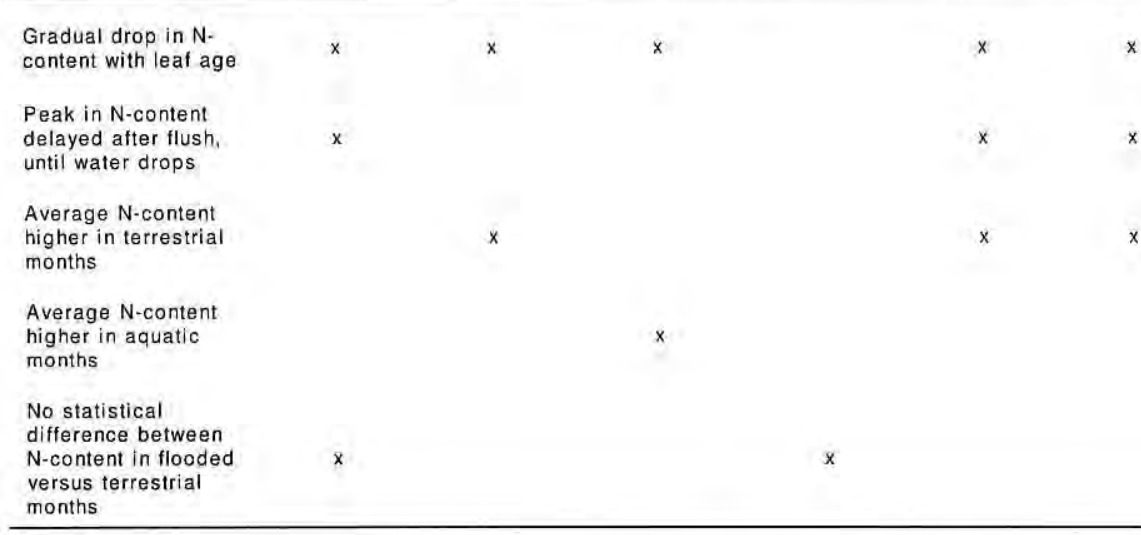

\section{Acknowledgments}

We wish to thank the Instituto Nacional de Pesquisas da Amazônia (INPA) for assistance. The field work in the varzea sites was made possible by financial support from the INPA/ Max-Planck Project.

\section{Literature cited}

Armbrüster, N. 1999. Auswirkungen von Überflutung auf Photosynthese, Blattphysiologie und Phänologie zweier Baumarten des zentralamazonischen Überschwemmungswaldes, Masters thesis, University of Oldenburg. Pp. 88.

Blom, C.W.P.M.; Voesenek, L.A.C.J. 1996. Flooding: the survival strategies of plants. TREE 11(7):290-295.

Ellsworth, D.S.; Reich, P.B. 1996. Photosynthesis and leaf nitrogen in five Amazonian tree species during early secondary succession. Ecology 77(2):581-594.

Ewing, K. 1996. Tolerance of four wetland plant species to flooding and sediment deposition. Environ. Experim. Botany 36(2):131-146.

Ferreira, L.V. 1991. O Efeito do Periodo de Inundação na Zonação de Comunidades, Fenologia e Regeneração em uma Floresta de Igapó na Amazonia Central. Masters thesis. pp. 161.

Field, C. 1983. Allocating leaf nitrogen for the maximization of carbon gain: leaf age as a control on the allocation program. Oecologia 56:341-347.

Field, C.; Mooney, H.A. 1983. Leaf age and seasonal effects on light, water, and nitrogen use efficiency in a California shrub. Oecologia 56:348-355.

Furch, B. 1984. Untersuchungen zur Überschwemmungstoleranz von Bäumen der Várzea und des Igapó: Blattpigmente. Biogeographica 19:77-83.

Gerdol, R.; Iacumin, P.; Marchesini, R.; Bragazza, L. 2000. Water- and nutrientuse efficiency of a deciduous species, Vaccinium myrtillus, and an evergreen species, Vaccinium vitis-idaea, in a subalpine dwarf shrub heath in the southern Alps, Italy, Oikos 88:19-32.

Gill, C.J. 1970. The flooding tolerance of woody species - a review. Forestry Abstracts 31(4):671-688.

Graffmann, K.C. 2000. Die Bedeutung der Druckventilation für die Sauerstoffversorgung des Wurzelsystems bei Bäumen der amazonischen Überschwemmungswälder. Doctoral thesis, University of Köln, 91 pp.

Gulmon, S.L.; Chu, C.C. 1981. The effects of light and nitrogen on photosynthesis, leaf 
characteristics, and dry matter allocation in chaparral shrub, Diplacus aurantiacus. Oecologia 49:207-212.

Hikosaka, K.; Terashima, I.; Katoh, S. 1994. Effects of leaf age, nitrogen nutrition and photon flux density on the distribution of nitrogen among leaves of a vine (Ipomoea tricolor Cav.) grown horizontally to avoid mutual shading of leaves. Oecologia 97:451-457.

Hook, D.D. 1984. Adaptations to flooding with fresh water. Pp. 265-294 in: Flooding and Plant Growth. T.T. Kozlowski (ed.). Academic Press, Orlando.

Joly, C.A.; Crawford, R.M.M. 1982. Variation in tolerance and metabolic responses to flooding in some tropical trees, J. Exp. Bot. 33(135):799-809.

Junk, W.J. 1989. Flood tolerance and tree distribution in Central Amazonian floodplains. Pp. 47-64 in: Tropical Forests: Botanical dynamics, speciation and diversity. L.B. Nielsen, I.C. Nielsen; H. Balslev, Eds. Academic Press London.

Kozlowski, T.T. 1984. Responses of Woody Plants to Flooding: Pp. $129-163$ in: T.T. Kozlowski: Flooding and Plant Growth. Academic Press.

Maia, L.M.A. 1997. Influência do Pulso de Inundação na Fisiologia, Fenologia e Produção de Frutos de Hevea spruceana (Euphorbiaceae) e Eschweilera tenuifolia (Lecythidaceae), em Área Inundável de Igapó da Amazônia Central. Doctoral thesis, INPA/FUA Manaus. 186 pp.

May, D.J.; Killingbeck, K.T. 1992. Effects of preventing nutrient resorption on plant fitness and foliar nutrient dynamics. Ecology 73:1868-1878.

Medina, E. 1984. Nutrient balance and physiological processes at the leaf level. Pp. 134154 in: Physiological Ecology of Plants of the Wet Tropics. Medina, E., Mooney, H.A.; Vazques-Yanes, C. (eds.) Junk Publ. Kluwer, Boston.

Meyer, U. 1991. Feinwurzelsysteme und Mykorrhizatypen als Anpassungsmechanismen in Zentralamazonischen Überschwemmungswäldern - Igapó und
Várzea. Doctoral thesis, University of Hohenheim. pp. 230.

Millard, P.; Proe, M.F. 1991. Leaf demography and the seasonal internal cycling of nitrogen in sycamore (Acer pseudoplatanus L.) seedlings in relation to nitrogen supply. New Phytologist 117:587-596.

Osman, A.M.; Milthorpe, F.L. 1971. Photosynthesis of wheat leaves in relation to age, illuminance and nutrient supply. II. Results. Photosynthetica 5:61-70.

Parolin, P. 1997. Auswirkungen periodischer Vernässung und Überflutung auf Phänologie, Photosynthese und Blattphysiologie von Baumarten unterschiedlicher Wachstumsstrategie in $z$ entral a mazon $i$ sche $n$ Überschwemmungsgebieten. Herbert Utz Verlag Wissenschaft, München. 166 pp.

Parolin, P. 2000. Phenology and $\mathrm{CO}_{2}$-assimilation of trees in Central Amazonian floodplains. J. Trop. Ecol. 16(3):465-473.

Parolin, P. 2001. Morphological and physiological adjustments to waterlogging and drought in seedlings of Amazonian floodplain trees. Oecologia; 128: 326-335

Pezeshki, S.R. 1987. Gas exchange response of tupelo-gum (Nyssa aquatica L.) to flooding and salinity. Photosynthetica 21(4):489493.

Pezeshki, S.R.; Pardue, J.H.; DeLaune, R.D. 1996. Leaf gas exchange and growth of flood-tolerant and flood-sensitive tree species under low soil redox conditions. Tree Physiology 16:453-458.

Poorter, H.; Remkes, C. 1990. Leaf area ratio and net assimilation rate of 24 wild species differing in relative growth rate. Oecologia 83:553-559.

Prance, G.T. 1979. Notes on the vegetation of Amazonia. III. Terminology of Amazonian forest types subjected to inundation. Brittonia 31:26-38.

Raison, R.J.; Myers, B.J. 1992. The biology of a forest growth experiment: linking water and nitrogen availability to the growth of Pinus radiata. Forest Ecology and Management 52:279-308.

Reich, P.B.; Walters, M.B.; Ellsworth, D.S. 
1991. Leaf age and season influence the relationships between leaf nitrogen, leaf mass per area, and photosynthesis in maple and oak trees. Plant, Cell and Environment 14:251-259.

Reich, P.B.; Walters, M.B.; Ellsworth, D.S.; Uhl, C. 1994. Photosynthesis-nitrogen relations in Amazonian tree species. Oecologia 97:62-72.

Sanchez, E.E.; Rithetti, T.L.; Sugar, D.; Lombard, P.B. 1991. Recycling of nitrogen in field-grown 'comice' pears. $J$. Hortic. Sci. 66:479-486.

Schlüter, U.-B.; Furch, B. 1992. Morphologische, anatomische und physiologische Untersuchungen zur Überflutungstoleranz des Baumes Macrolobium acaciaefolium, charakteristisch für die Weiß- und Schwarzwasserüberschwemmungswälder bei Manaus, Amazonas. Amazoniana 12(1): 51-69.

Schlüter, U.-B. 1989. Morphologische, anatomische und physiologische Untersuchungen zur Überflutungstoleranz zweier charakteristischer Baumarten des Weiß- und Schwarzwasser Überschwemmungswaldes bei Manaus. Ein Beitrag zur Ökosystemanalyse von Várzea und Igapó Zentralamazoniens. Doctoral thesis, University of Kiel, pp. 147.

Schlüter, U.-B.; Furch, B.; Joly, C.A. 1993. Physiological and anatomical adaptations by young Astrocaryum jauari Mart. (Arecaceae) in periodically inundated biotopes of Central Amazonia. Biotropica 25(4):384-396.

Scholander, P.F.; Perez, M.O. 1968, Sap tension in flooded trees and bushes of the Amazon. Plant Physiol. 43:1870-1873.

Swaine, M.D.; Whitmore, T.C. 1988. On the definition of ecological species groups in tropical rain forests. Vegetatio 75:81-86.

Tremolieres, M.; Schnitzler, A.; Sanchez-Perez, J.M,; Schmitt, D,D. 1999. Changes in foliar nutrient content and resorption in Fraxinus excelsior L., Ulmus minor Mill. and Clematis vitalba $\mathrm{L}$. after prevention of floods. Annals of Forest Science 56(8):641-650.
Waldhoff, D.; Junk, W.J.; Furch, B. 1998. Responses of three Central Amazonian tree species to drought and flooding under controlled conditions. Intern. J. Ecol. Env. 24:237-252.

Walters, M.B.; Reich, P.B. 1989. Response of Ulmus americana seedlings to varying nitrogen and water status. 1. Photosynthesis and growth. Tree Physiology 5:159-172.

Wittmann, F.; Parolin, P. 1999. Phenology of six tree species from Central Amazonian várzea. Ecotropica 5:51-57.

Worbes, M. 1986. Lebensbedingungen und Holzwachstum in zentralamazonischen Überschwemmungswäldern. Scripta Geobotanica: 1-112.

Worbes, M. 1989. Growth rings, increment and age of trees in inundation forests, savannas and a mountain forest in the neotropics. IAWA Bulletin n.s. 10(2):109-122.

Worbes, M. 1992. Occurrence of seasonal climate and tree-ring research in the tropics. Lundqua Report 34:338-342.

Worbes, M. 1997. The forest ecosystem of the floodplains. Pp. 223-266 in: The Central Amazon Floodplain: Ecology of a Pulsing System. W.J. Junk, (ed.). Ecological Studies 126, Springer Verlag, Heidelberg.

Worbes, M.; Klinge, H.; Revilla, J.D.; Martius, C. 1992. On the dynamics, floristic subdivision and geographical distribution of Várzea forests in Central Amazonia. Journal of Vegetation Science 3:553-564.

\section{Aceito para publicação em $06 / 06 / 2002$}

